\title{
Education of First Grade Pupils in Protection Topics in the Czech Republic - Central Europ
}

\author{
Lukas Stárek ${ }^{1, *} \&$ Jarmila Klugerová ${ }^{1}$ \\ ${ }^{1}$ Department of Special Education, Univrzita Jana Amose Komesnského Praha, Prag, Czech Republic \\ *Correspondence: Department of Special Education, Univrzita Jana Amose Komesnského Praha, Roháčova 63 Prag \\ 3, 130 00, Czech Republic. Tel: 420-777-905-823. E-mail: starek.lukas@ujak.cz
}

Received: April 6, 2020

Accepted: June 8, $2020 \quad$ Online Published: June 20, 2020

doi:10.5430/wje.v10n3p127

URL: https://doi.org/10.5430/wje.v10n3p127

\begin{abstract}
Each of us in our lives will face emergencies, whether a fire, accident, traffic collision or natural disaster, and it is crucial that we know how to recognise them and how to adequately react. The text presents the knowledge level in protection and safety among first to third grade primary school pupils living in socioeconomically marginalised localities, in Central Europ - specifically in the Czech Republic. Education of children and pupils in areas of ppilation protection is becoming the number on topic. The challenge is to alert and motivate teachers to continue with topics that develop not only knowledge but also the perception of the outside world and the awareness of threats and dangers that may affect the development of the child or pupil. The findings are the outcome from the project weeks implemented over two years and yielding interesting findings that formed the basis of practical recommendations.
\end{abstract}

Keywords: background, safety, protection, pupil, upbringing

\section{Introduction}

Each of us in our lives will face emergencies, whether a fire, accident, traffic collision or natural disaster, and it is crucial that we know how to recognise them and how to adequately react. The legally-guaranteed protection in the case of emergencies and for the protection of life and health of the citizenry or property is primarily the remit of the integrated emergency response system. Protection provided by the integrated emergency response system does not arrive in mere seconds, and a person is thus forced by necessity to deal with the situation and help as well. For this reason, it remains necessary to support and perfect the education and training of citizens, and it proves effective that this process is supported by schools or educational institutions.

The term "protection of the citizenry" has been defined by, for example, Fiala and Vilášek as "...the system intended to protect safeguarded activities, especially of the citizenry during emergencies. Protection of the citizenry is by its nature an integrated system that entails bonds, relations and specific measures" (Fiala and Vilášek, 2010, p. 65).

Considering the definition of this term, it is also necessary to mention the legislative definition that emerges from Act no. 239/2000 Coll. on the Integrated Emergency Response System and Amendments to Certain Acts, i.e. “...performing tasks of civil protection, especially alerts, evacuation, providing shelter and emergency survival of the citizenry and other measures to safeguard the protection of its life, health and property" (Act no. 239/2000 Coll. on the Integrated Emergency Response System and Amendments to Certain Acts ).

\subsection{Education in the Protection of the Citizenry in the Czech Republic, Central Europ}

Over several years, a variety of concepts have focused on the correct and effective adjustment of the educational process regarding protection of the citizenry. One such document is Koncepce prípravy občanů $k$ obraně státu 2019-2024 (Conceptualisation of Preparation of Citizens for the Protection of the State 2019-2024). It follows on from Koncepce př́pravy občanů k obraně státu na roky 2013-2018 (Conceptualisation of Preparation of Citizens for the Protection of the State 2013-2018). One of the main outputs of Koncepce př́pravy občanů k obrané státu 2019-2024 is evidence of several critical defects. A crucial finding was the fact that educational staff at primary and secondary schools are not sufficiently prepared to teach in the field of state defence. There is a lack of information, training or materials that may be suitable for teachers. The findings above thus show that positive results in the protection of the 
citizenry at elementary schools are not being achieved. The document goes on to point out that the teachers themselves at several schools are not devoting time to the protection of the citizenry or the state. However, this topic is entrusted to other organisations that replace the role of educational staff. Therefore, it is necessary to improve the quality of education at primary and secondary schools and thus improve the current state of preparation of pupils and students to protect the state.

The results of research conducted especially by the Fire Rescue Service of the Czech Republic point to the fact that one of the crucial factors that powerfully affect the level of a system of education is the evident high standards for the teaching staff. A comparison that applies here is the level of preparedness of pedagogical graduates at universities depends on the quality of their professional or specialist preparation. Following expert recommendation, the Government of the Czech Republic approved on $5^{\text {th }}$ October 2011 by its resolution no. 734 the material for the Incorporation of Topics called Ochrana člověka zamimořádných událostí, péče o zdraví a dopravní výchova (Protection of a Person during Emergencies, Care of Health and Traffic Education) into the course of the pedagogical faculty. "The aim of the material is to create a collective knowledge base (Foundation Course I) for the tertiary education of teachers. It should prepare graduates to be able to adequately react during the occurrence of an emergency and protect themselves and the children in their care. The material includes the knowledge bases intended to prepare future teachers who will teach the issue in question. (Foundation Course II; Foundation Course III)" (Ministry of the Interior - General Directorate of the Fire Rescue Service of the Czech Republic, online, citation, 2019-12-06).

The options and methods of applying into practice the aforementioned document depend on the possibilities of the specific university, specifically regarding accreditation and reaccreditation of courses connected to the professional preparation of teaching staff. Following on from the professional preparation itself, it is necessary to draw attention to other facts that help along the achievement of education in the given field. Specifically, it concerns the possibility of using prepared aids, textbooks or professional manuals.

\subsection{Education Delivered by a Framework Educational Programme for Primary Education}

The education as understood at the 1st grade of primary education is at its core about transferring from pre-primary education, which is tightly bound to the family, into a regular and systematic educational system. The cornerstones for achieving the educational objectives at the 1st grade of primary school education rest, essentially, on the development of individuality, of respect, of understanding and the possibility and interest of each child/pupil, including children/pupils with special educational needs and gifted and exceptionally gifted children/pupils. The educational system is based on the active component emphasising the practical nature, including the application of adequate methods where there is a motivation to teach the child/pupil more, leading them to teaching activities and to an understanding that it is possible to search, discover, create and find the suitable way in addressing problems or in a range of difficult life situations (Framework Educational Programme for Primary Education, 2017).

Key competencies are target categories expressed in the form of outputs. In the Czech curricular documents, they are generally formulated as: "a set of knowledge, skills, abilities, attitudes and values important for personal development and utilisation of each member of society. Their selection and approach are based on values generally accepted in society and on generally communicated ideas about which competencies of an individual contribute to his/her education, a satisfied and successful life and to strengthening the function of civil society" (Framework Educational Programme for Primary Education, 2017, p. 10).

Key competencies can be used at the general level as a valuable indicator of determining quality of education, not only within the process itself, but in terms of the outcomes. The educational objectives are, regarding content, an educational tool that should determine the educational direction or objective, but the role of the teacher is always as the person who implements and interprets the given educational aims to help the appropriately selected educational methods and grading system. Lessons should thus be planned and conceived so the given competency is gradually imparted to the children/pupils. "Each key competency is formed gradually in the pupils so that the constituent knowledge and skills of pupils obtained in various circumstances are interconnected" (Čechová et al., 2006, p. 12).

Veteška et al. (2011, p. 83) state that a part of the primary education stage under the Framework Educational Programme for Primary Education, include the following key competencies:

- for learning

- for problem solving

- communicative,

- $\quad$ social and personal, 
- civil,

- $\quad$ work $(2011$, p. 83)

The duty of primary schools lies also in the necessity of implementation so-called cross-curricular topics into an educational framework that pervades school topics. School should offer all subject areas of each cross-curricular topic. Their scope and method of implementation is set by the school's curriculum. These cross-curricular topics are as follows:

- personality and social education

- civics

- education for thinking of European and global contexts

- multicultural awareness

- environmental awareness

- media awareness

(Framework Educational Programme for Primary Education, 2017, p. 125)

Mastering key competencies can thus be regarded as a lifelong learning process since it interconnects teaching with the individual's life experience. And given that learning at its core is a lifelong process, this statement thus suggests the importance of individuality of the person and also his/her understanding in the way experience and life events are gained. Competencies are thus an integral part of life stories, and obtaining them may be conscious and unconscious. Both findings can be drawn on not only in the school environment but also in the family or the environment in which the individual/child lives. Competent behaviour itself is formed with regards to life stages, professional employment and partnered relationships. Competencies can be gained throughout an individual's life. Therefore, it is possible for someone to learn to be a competent person.

\section{The Individual and His/Her Background}

Equal opportunity and fair access to quality education of children/pupils/students should be among the basic pillars of human rights. A considerable influence, not only in social, economic and cultural terms, is the family, which impacts the results of the school success rate of pupils, the educational process and, last but not least, the life and professional course. School can also be included among the crucial pillars that have an undoubtable impact on education and the whole development of an individual. Therefore, the following subchapters address the cooperation and mutual support of the family and school regarding efficacy within the educational process of the child/pupil.

\subsection{Family}

With social changes come changes to the family environment. A critical change includes the relationships between parents and children themselves at moments where parents have no idea how the child spends his/her free time, what interests them and what friends they have. The social tempo, which is not only felt by the parents themselves and which stems from a stressful environment that is hectic and ethically, morally or, in certain areas, socially untethered, also opens up gulfs in family relationships. The family is more isolated from the outside world, and it is less able to cope with the process of raising children. It thus attempts to shift the certain educational areas/responsibility of raising children to various institutions and specialists.

The definition of the term "family" cannot be unambiguously characterised or defined. The position of the family as the educational actor has changed over recent years, and the same is true over the course of history as society has changed. Generally, the family is defined in connection with its position in the social system. Given the focus of the article, the sociological perception of the family is the primary concern. The most concise definition is thus the definition according to the Large Sociological Dictionary "...the family is the most important social group and institution that is a basic element of the social structure and basic economic unit that has the primary function of propagating the human species and raising or socialising the young and transmitting cultural examples and maintaining the continuity of cultural development" (Linhart, J. et al., 1996, p. 28).

The significance of the family for a child is undeniable, whether it is a feature of the emotional backdrop, which is the hardest to fulfil today, or security and safety, but also whether it is a sufficient impetus and transmission of experience that derives from the role of parents or citizens of a given country in relation to the cultural identity.

In today's society, families differ according to their own social status that may positively or negatively influence the 
child. Social status is defined as "...the social position that the individual or group has in the vertical social hierarchy. There is social inequality between people with different status. Differing social statuses are evident in the level of education, qualification, wealth, power position, etc. Social levels, classes and property groups in this way form. Individual property groups also have distinct social approbation or prestige. Social status is connected to various lifestyles" (Průcha, Walterová, Mareš, 2013, p. 272).

One of the factors that influences the raising and education of a child is the level of education attained by the parents themselves. The family and its social status are determined in relation to the actual level of education because, according to Leiman (1996), education contributes to a person's improved facilities and his/her future career and thus position in society.

"The interconnection of upbringing and education with the economic, political and cultural development is a manifestation of their close connection to the development of the social structure. In traditional society, the social position was predetermined by tradition and origin. Even though there was mobility (wars, domestic service, usury, etc.), education was more of a privilege, a confirmation and symbol of the existing status then a tool of attainment (with the exception of a small group of officials and the priesthood). In modern societies, it plays one of the most important roles of integrating people into a professional structure" (Havlík and Kot’a, 2011, p. 81).

Family impact or influence on education is evident, even in the field of professional career, as the family becomes the actor that may determine the very direction in this area when, for example, given the age of the child, his or her dreams and wishes, which have their justified place, are not a possible starting point. The educational institution itself is then also related to this influence. The gist of the text is that the influencing factor is thus the cultural background of the family and its economic capital in a broader conception.

Inequalities in education, which are influenced by various factors, are present everywhere in the world. They may be caused by both an attitude to study, interest and will to study or ability itself and also, for example, race, gender or religion. Problems in relation to social justice and cohesion could be included in this area. In developed countries, including the Czech Republic, the level of inequality is decreasing, especially between urban and rural areas.

The already conducted research that examined this topic, such as Study into the Attitude toward Education: Equal attitude toward education in the Czech Republic: situation and recommendation shows that the education of children directly corresponds to the initial situation in the family. Across the spectrum of university students, the percent of those who have university-educated parents or families from a higher socioeconomic status.

"Stark differences are statistically demonstrated: the likelihood of university studies for a child from a "professional" family is more than twice as high than for a child from a "static working family" (Matějü, Večerník, 1998, p. 59).

Another factor that influences upbringing and education is the socioeconomic level of the parents. The financial situation of the family, primarily the parents, may encourage, or conversely prevent, the attainment of a level of education the child wants to achieve.

According to Možný (2002), the socioeconomic situation of parents affects several areas that impact upon the child's educational process. One such area is the living arrangements of the family where the level of incomes is reflected in the size and location of the home. Children who have their own rooms and more opportunity to concentrate on studying have different chances than children who share a room with siblings and have their concentration disrupted by the actions of their siblings. A suitably secured family can also afford to live in a "better neighbourhood" where the child may interact with equally advantaged friends and attend an "elite" school.

Danielsbacka et al. (2017) also interconnect the socioeconomic status with the degree of attention focused on the child. They put forward the idea that parents with a higher socioeconomic status devote more attention to a child. The parents' attention is itself one of the constituent parts that affect the school results of the child.

The family arrangement influences, along with the operation of the family, the upbringing and education of the child. The internal arrangement of the family has a close influence on the process of school success rate of the child. Today's family setup, in terms of number of children, is largely limited to one or two children. Within larger sibling bonds, various educational processes/approaches are reflected in each sibling. The general claim can be made that more responsibility is placed on the older sibling as the parents were able to devote a greater degree of attention to $\mathrm{him} / \mathrm{her}$. Consequently, parents did not devote so much attention to the younger siblings during childhood. This general claim can also be supported with regard to historically significant figures among whom can be included Alfred Adler (Austrian physician and psychologist), whose claim was based on the idea that only-children and first-borns have the best school results. They are under more pressure and receive more attention than other children in the family. Family size and birth order influence the educational process and its results. 
In each family, conflicts may play out. Their source may be for diverse reasons (infidelity, suspicion of infidelity, insufficient funds, unsuitable behaviour of one of the partners...). These conflicts may adversely affect the child, especially in terms of mental development or psychological needs, following on the social development of the child. The parents must not at all feel that their conflicts affect or influence their child. These experiences will be deeply etched into the memory of the child.

Single-parent families, where one parent dies, leaves or a child is born out of wedlock, may have a similar adverse effect not on the educational process. Matoušek (2010, p. 45) contends that "unlike two-parent families, single-parent families are more often threatened by unemployment, lack of access to adequate housing, social isolation, poverty and social exclusion".

\subsection{The School and the Pupil}

Communication, trust and respect are areas that serve to ensure effective cooperation between a family and school. The parent or the school has a joint-responsibility in the educational process of the child. The positive impact on the child cannot be ensured without mutual cooperation. Within the scope of this cooperation between the family and the school, there are various prominent factors that may support the function, or cause the malfunction, of this mutually cooperative apparatus. They are, in particular, the personality of teaching staff in terms of approach to the family, professional age, experiences, the atmosphere in the given class when the issue is an over-crowded class, relations in the class, bullying, group work - both in positive and negative terms; how a parent regards school, whether he/she attended the school and if he/she has roots there or whether it concerns a school that suits the family and there are no connections to it that may be, for example, in the context of the school's specialisation.

To meet the efficacy of the cooperation between a family and school, Krejčová and Kargerová (2003) present the following list of ten points for cooperation with a family:

1. We respect the role of parents. Various factors will be able to influence a child's development, yet parents are the most influential. They have the right, and at the same time the duty, to make important decisions concerning their children. Let's bear this role in mind in each situation and deal with it accordingly. Let's build mutual respect between the teaching team and families.

2. We maintain confidentiality. During the child's school attendance as well as after, parents have a right to protect their personal information. Information requested from families are critical in the effective provision of a child's education. Only the family/parents have this information available. When this information must be provided to others, we notify the parents in advance and request their consent.

3. We inform parents of expectations that we have for ourselves. Especially at the start of the school year (or of school attendance or still before the child enters school), but even during the school year, we find out how the parents conceive their child's education and the mutual cooperation. Openly present intentions, objectives and plans.

4. We support cooperation with parents and offer more strategies for their involvement. Each family is specific. What is suitable for one may not be important for another. We are flexible and creative so that a family is able to have a choice according to its own preferences and possibilities.

5. We respect that the family itself will select its specific form of cooperation. The task is thus to offer to the family the broadest range of options possible. The option/way of cooperation selected by the family will be up to the family itself.

6. We strive to involve the whole family. We encourage not only the child's parents to cooperate. Other members of the family and their friends may contribute.

7. We plan parent meetings and consultations at a time that suits the parents. A parent may choose based on its own time possibilities when to come for a consultation. Having a consultation timetable available will better prepare them.

8. We focus on the family's strengths and provide positive feedback. We emphasise the family's strengths and any success achieved. Families know that we appreciate their cooperation and involvement in the class.

9. We cooperate with the school's other partners. We support not only the community life but also other institutions and organisations that we cooperate with and make use of their services. Openly cooperate and coordinate in various fields.

10. We understand that it won't all come immediately. We build relations and intensive cooperation with parents gradually, building gradually on small victories. It requires time and effort. We know it's demanding, but we don't 
give in.

The parent should be interested in how the child views school and whether he/she is coping or not at school. Cooperation with the school should promote a feeling of cooperation and definite belonging. Space is opened here for more specific understanding of the child in terms of easier identification of his/her strengths and weaknesses, which can be built upon through directing leisure activities and professional preparation. Suitable cooperative communication also happens within the transmission of information that children bring from school. The parent may easily verify the information, obtain reflections on working with the child at school and question everything concerned with the educational process. An educational institution may affect/influence not only a child/pupil but also their family.

From the teacher's point of view, well-established cooperation is a great aid in determining an adequate level of access to a pupil. If the teacher correctly evaluates the causes of the child's behaviour and has the opportunity to compare his/her own observations or knowledge with the information from the parents, he/she can honour his/her professional commitment to achieve the learning objectives in accordance with the appropriate approach to a particular pupil. The teacher must be realistic, so not every parent will want to cooperate. It is the duty of the school to inform parents about punishments and ways of solving the problems of children and to direct them to institutions or organisations that can help the child, parents and family.

Even the educational institution or teachers themselves may have an expectation in relation to the family/parents. According to Rabušicová and Pol (1996), these are:

- The parents will be willing to resolve the problem;

- The parents will create a positive home environment;

- The parents will manifest a duty of care for their child and check it;

- The parents will ensure the children bring aids to school;

- The parents will oversee the fulfilment of the teacher's requests;

- The parents will be interested in meeting the teacher.

\section{Methodology}

The main research aim is to determine the knowledge level in protection and safety among primary school pupils from the first to third grade in socioeconomically marginalised localities. Building upon these findings, it will apply the topic module of the project weeks and determine the knowledge level of the given target group.

Constituent research questions are created by building on the main research objective. Three research questions were set in total. They were:

Research question no. 1: What is the initial level of competencies of pupils from socioeconomically disadvantaged backgrounds in the areas of safety and protection of health and life?

Research question no. 2: How were civic competencies of the target group of pupils from socioeconomically backgrounds perfected by the implementation of the project weeks?

Research question no. 3: How can the motivation of pupils be supported in the classroom to actively involve them in educational processes?

\subsection{Research Method}

The research method incorporated several fields of study so that the research aim was met. The basic research area has been defined in this chapter, not only in terms of the general characteristics of the examined issue, but also with regards of the characteristics of the target group, the environment or ethical nature of the research.

\subsection{Initial Information}

The empirical part follows from the project - Development of Civic Competencies in Safety and Protection of the Citizenry among Pupils from Socioeconomically Disadvantaged Backgrounds - where thematic project weeks that concluded with a test/questionnaire were, among others, implemented. The thematic areas/modules should be aimed at increasing the knowledge of pupils, specifically so that a pupil would understand the evident danger connected with risks of everyday life (traffic, chemical substances in the home, electric current, sports and hobbies), with fire and with an emergency, then know how to call for help (using any of the learned methods) and, last but not least, to know how to use emergency numbers to make calls and master basic communication methods with the operator 
(suitable for their age).

The implementation team of pedagogical coordinators composed 10 educational modules and each of them was concluded by a verification test intended for the given target thematic area. These thematic areas were:

Module no. 1: PRINCIPLES OF THE CORRECT ROUTE TO SCHOOL

Module no. 2: WHEN, WHERE AND HOW TO CORRECTLY REPORT AN EMERGENCY

Module no. 3: PRINCIPLES WHEN EVACUATING A BUILDING

Module no. 4: PRINCIPLES WHEN ENCOUNTERING ILLEGAL BEHAVIOUR I.

Module no. 5: PRINCIPLES WHEN ENCOUNTERING ILLEGAL BEHAVIOUR II.

Module no. 6: PRINCIPLES OF CORRECT BEHAVIOUR ON THE TRAIN AND RAILWAY

Module no. 7: GETTING LOST IN NATURE

Module no. 8: FIRST RESPONDERS AND UNIFORMS

Module no. 9: FIRE, HOW TO PREVENT IT, ITS CAUSES AND CONSEQUENCES I.

Module no. 10: FIRE, HOW TO PREVENT IT, ITS CAUSES AND CONSEQUENCES II.

Given the main research aim and constituent research questions, we have decided to use the quantitative research method.

To distribute the questionnaires that were devised in a battery of tests for individual project weeks, we decided to send it out via email. This form was agreed by the participating primary school teachers at a personal meeting that happened as part of the aforementioned project "Development of Civic Competencies in Safety and Protection of the Citizenry among Pupils from Socioeconomically Disadvantaged Backgrounds" The test for the given module was always sent by the end of the previous month; the teachers or the pupils always completed only one module test at a time. They did not receive all the tests at once. Teachers always had the option of face-to-face, telephone or email consultation. At the participating schools, a single week was set when the project activities were carried out, and it ended with the completion of the test of the given thematic module. The tests were then sent by post to the administrative office of the implementation team of a given project.

Ten primary schools were involved in the project activity in total. Ten students from socioeconomically disadvantaged backgrounds were supported at each school. The activities and also the module tests for each project week were intended for all the other children from a given group. And they were not counted in the results, specifically with regards to the pre-determined indicators of the participating/supported individuals. Data from the questionnaire obtained during the pilot test was included in the interpretation of data. Regarding the interaction, the return rate of the module tests was a proven $100 \%$. Therefore, 100 questionnaires/module tests in total were used throughout school year.

Given the essential setup of project, the target group was strictly delineated. In particular, it concerned the specification of the given target group - i.e. first to third grade primary school pupils in socioeconomically disadvantaged localities. More specifically, it concerned first to third grade pupils who attended the after school programme. Additional specifications for the selection of the studied group of individuals were not set.

Given the fact that all the material - project weeks and the follow-on module tests were never used, it was necessary to ensure their verification. Verification was done by one of the participating primary schools where verification was carried out on the monitored sample of children. No changes occurred in the pilot test - either in the content or in the structure of the parts. By using the pre-study/pilot test, we wanted to find out whether the given questions were comprehensible and unambiguous. The essential modifications were to ask a question in the positive sense modifications included formulating the questions as "tick the correct answer". This specific correction emerged from the age-group of the pupils. Furthermore, the partial phrases were edited so that the text was unambiguous and comprehensible even for the given target group of pupils - in terms of age since it was completed by children from the first to third grades of primary schools from socioeconomically disadvantaged localities.

\section{Results}

\subsection{Initial Knowledge Survey}

The initial knowledge survey focused on several critical areas that were connected to the thematic areas of safety and protection of health and life of pupils from the first to third grades of schools that are in socioeconomically 
marginalised localities.

Given the scope of the text, the main thematic findings are presented at the general level. They target the acquired knowledge of respondents in awareness of emergency numbers; principles of safe conduct; anti-fire protection; protection of health and behaviour on railway tracks.

\section{Emergency numbers}

a $60 \%$ of pupils knew this term. Half of the children knew that they had to provide factual information during the call (what, where or their name).

- The most well-known number was 150 ( $72 \%$ of pupils) and 158 ( $70 \%$ of pupils), then 155 (66\% of pupils). In contrast, fewer pupils knew number 112 (41\% of pupils).

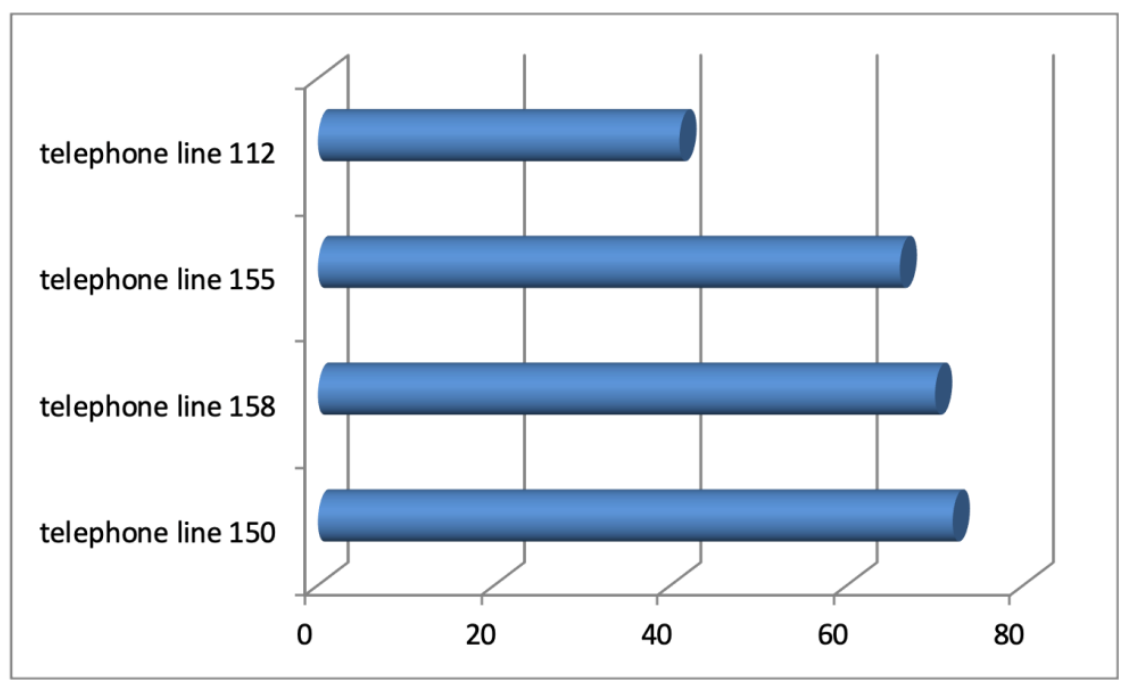

Image 1. Knowledge of Respondents of Emergency Lines

Source: own research

\section{Principles of safe conduct}

a $15 \%$ of pupils would get into a lift with a stranger.

口 Pupils were less likely to be lured by the telephone.

口 Pupils would more likely open the door to acquaintances and relatives.

- $29 \%$ of pupils informed parents where they were going or the time of their return.

\section{Fire protection}

- $24 \%$ of pupils think that a fire could not start from a small spark and $13 \%$ of pupils that it could not start from a match thrown into dry grass.

\section{Health protection}

A After a walk, $30 \%$ of respondents checked for ticks, and 31\% washed their hands and body.

- On a trip in summer (or to the water) $45 \%$ would take water to drink, and $27 \%$ would pack sunscreen. (Only $15 \%$ of pupils would take both.) In addition, pupils mentioned bathing costumes and other swimming aids.

- $45 \%$ would tell an adult about finding a syringe. In contrast, $13 \%$ would do nothing. $5 \%$ did not know what to do, and a full $11 \%$ would try to throw it in the rubbish.

- $13 \%$ of pupils did not consider jumping into unfamiliar water dangerous. And only $34 \%$ stated the proper risk (unknown water/depth, chance of injury).

- The majority of pupils know about the risk of injury at home. They mentioned cutting with knives, jumping, running, climbing on furniture, being in the vicinity of the stove, appliances, wood stoves and heating and taking the stairs as dangerous activities. 


\section{Behaviour on Train Tracks}

- $4 \%$ of pupils did not know it was forbidden to play close to the tracks or walk on the tracks. $11 \%$ did not know it was forbidden to cross anywhere other than at a crossing.

\section{Partial summary of the initial survey}

The aforementioned study and partial outputs show that children/pupils must be shown the existence of the possibility of various dangers whether to health, life, property or the state. In each of the areas of the questionnaire research, there is a higher proportion of respondents whose answers stimulated discussion on awareness itself of risks and risky behaviour in their life and surroundings. The basic presumption is that we avoid or are able to at least minimise such injuries, harm and losses, that we know about them and we could talk about/show what these risks/risky situations are and respond appropriately as part of practical lessons. It is thus to target the form of prevention through activities that lead to the preparation of children and pupils in an emergency. In the evaluation process, it was shown that testing the knowledge of pupils through this method is possible. However, it requires very precise preparation of the questions asked and consideration of the actual abilities of the children at different ages. The use of various questions and schematics where pupils may easily grasp the given situation and respond to the question with comprehension.

\subsection{Survey after a Year of Activities}

The number of respondents is after a year of the project activity identical to the initial information survey.

Given the scope of the paper, the findings from the topic-based survey that targets the obtained knowledge from respondents in knowledge of emergency numbers, principles of safe conduct; fire protection; protection of health and behaviour on train tracks are presented. The aforementioned areas are thematically identical to those within the initial knowledge survey.

\section{Emergency number}

a $91 \%$ of children knew this term, and its proportion significantly grew - in the last round it was only $60 \%$ of pupils.

- The majority of pupils also knew that they had to provide factual information during the call (what happened and where or their names). In this case, there was a significant improvement. Pupils were two to three times better informed about what they should do compared to the last round.

- The best-known number was 150 (93\% of pupils). Then came number 158 (90\% of pupils) and 155 (90\% of pupils). In contrast, the less well-known was number 112. (74\% of pupils). Knowledge of all the lines significantly increased compared to the last round - there was a growth of approximately $20 \%$. The least well-known number 112 almost reached a level of familiarity similar to the other number.

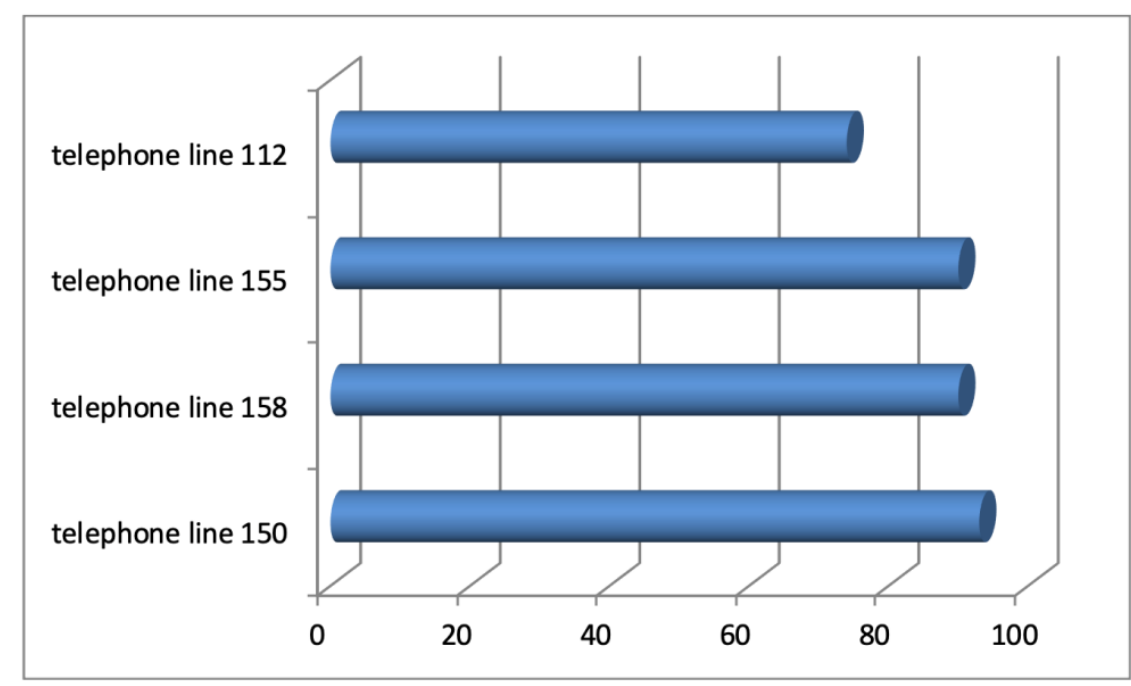

Image 2. Knowledge of Respondents of Emergency Lines after a Year of Activity

Source: own research 


\section{Principles of safe conduct}

Only $2 \%$ of pupils would get into a lift with a stranger, which was a significant drop in comparison to the last round $(15 \%)$.

- Fewer pupils allowed themselves to be tempted on the phone. Based on the responses, almost all the pupils were wary. The level was roughly the same as in the last round.

- Pupils would mostly open doors for parents and relatives or to those whom they know. A fifth of pupils stated that they would open it to no one. In contrast, one pupil was found who would open it to anyone. The proportion of parents and acquaintances to whom they would open the door rose since last time, whereas the proportion of those responding with "no one" fell. Obviously, a portion of pupils understood this as "no one except parents".

- $69 \%$ of pupils (and almost a fifth of children gave a greeting) informed their parents about where they were walking. Meanwhile, only about $60 \%$ gave a greeting in the last round, and the place, and route was only given as information by a fourth of the children.

\section{Fire protection}

- Only $2 \%$ of pupils thought that a fire could not start from a small spark. (In the last round, it was practically a quarter of the children) and 3\% of pupils stated that a fire could not start from a match thrown into dry grass (last round $-13 \%$ ). It could be said, more or less, the rate of pupils being informed almost reached the maximum.

\section{Protection of health}

- After a walk, $79 \%$ checked themselves for ticks, and 19\% washed their hands/body. Compared to last year's initial survey, there was considerable growth in mention of ticks. Only $30 \%$ of pupils mentioned this activity last year. Thus awareness-raising worked.

On trips in the summer (or to the water) $57 \%$ would take water to drink and $46 \%$ sunscreen (only $23 \%$ both). These two items significantly grew to the detriment of other items. Furthermore, pupils mentioned bathing costumes, goggles, headgear and other swimming aids. It can be stated that pupils mentioned more important equipment during last year's round.

- $20 \%$ of pupils would report finding a syringe to an adult/parent. A third of pupils stated that they would not touch it. (In the initial findings, it was a quarter.) Half of children would call the police (a fifth in the initial findings).

- $11 \%$ of pupils did not consider jumping into unfamiliar water dangerous. This only $2 \%$ less than in the initial survey. In this case, there was no improvement. Other pupils recognised the risk. The majority of them correctly stated the right reason (unfamiliar water/depth, chance of injury).

- Similarly, as in the initial survey, the majority of children knew about the risk of injury at home. They mentioned cutting with knives, jumping, running, climbing on furniture, being in the vicinity of the stove, appliances, wood stoves and heating and taking the stairs as dangerous activities.

\section{Behaviour near train tracks}

口 $2 \%$ of pupils did not know it was forbidden to play close to the tracks or walk on the tracks. $11 \%$ did not know it was forbidden to cross anywhere other than at a crossing. In this regard, the situation remained at a similar level as in the initial findings. Obviously, the rate of being informed was generally in total high with the exception of the prohibition on crossing.

\subsection{Survey after Two Years of Activities}

The number of respondents in the second year of the project activities is identical to the initial information survey.

Given the scope of the paper, the findings from the topic-based survey that target the obtained knowledge from respondents in knowledge of emergency numbers, principles of safe conduct; fire protection; protection of health and behaviour on train tracks are presented. The aforementioned areas are thematically identical.

\section{Emergency number}

- $96 \%$ of children knew this term in the last round, which is a little more than during the previous school year (91\%) and considerably more than two years ago. The majority of children immediately recalled the main components of the emergency response system or that that serious incidents are reported using the 
emergency number. Other children recalled the 112 number or other emergency numbers.

The majority of pupils knew that they must provide factual information during the call (what happened and where or their names). A full $60 \%$ of them named all three pieces of information and only $6 \%$ of pupils, in contrast, did not name any. In this case, there was a significant improvement compared to the previous year.

- Awareness of all numbers was very high, and the originally significant differences in awareness of the numbers disappeared. The best known number was 150 (93\% of pupils) then 158 (95\% of pupils) and 155 $(87 \%)$. The comparatively least well-known was number $112(80 \%$ of pupils). The most significant year-on-year changes occurred between 2017 and 2018 when awareness of all numbers grew. In 2019, knowledge of lines 150 and 158 remained at the same level as last year; knowledge of 112 slightly increased year-on-year, and knowledge of 155 dropped somewhat in contrast.

\section{Principles of safe conduct}

- $6 \%$ of pupils would get into a lift with a stranger. This was a year-on-year increase of the proportion, but it remained lower than in comparison with the results from 2017, which was a significant drop in comparison to the last round (15\%).

Regarding offers to meet over the telephone, pupils were less wary than in the previous year. The proportion of pupils who would inform their parents about this type of situation significantly grew compared to the previous year.

- Pupils would open the door most of all for parents and acquaintances or someone who they know. A fifth of pupils stated that it would be for no one. The results almost did not change year-on-year.

- This year the pupils would inform parents where they were going without hesitation (92\%). Half of them had become used to informing parents of the time of their return, which was a significant change compared to the last round.

\section{Fire protection}

O Only $2 \%$ of pupils over the school year, just as last year, thought that a fire could not start from a small spark. Similarly, only a small percentage of pupils ( $2 \%$ in $2019,3 \%$ in 2018$)$ stated that a fire could not start from a match thrown into dry grass. In both questions, the situation significantly improved in comparison to 2017.

\section{Protection of health}

- After a walk, $80 \%$ checked themselves for ticks, and $9 \%$ washed their hands/body. Other students either stated nothing or mentioned a different domestic activity. The higher rate of being informed about the dangers of ticks was noticeable between 2017 and 2018.

O On trips in the summer (or to the water), $77 \%$ would take water to drink, and $56 \%$ would take sunscreen and, now, $46 \%$ headgear. A full $46 \%$ of pupils would take a drink and sunscreen at the same time - this is twice as much as last year. These two items grew significantly year-on-year to the detriment of other items, both this year and last year.

The proportion of pupils who would not pick up a syringe significantly grew from $25 \%$ to $48 \%$. Two fifths of them would call the police in this case - this here was a drop compared to last year, despite the proportion of these children being twice as high as in 2017.

口 $8 \%$ of pupils did not consider jumping into unfamiliar water as dangerous. The rate of being informed slightly improved. (In 2017, it was 13\%). Nonetheless, the majority of pupils (91\%) recognised the risk, and the majority (88\%) gave one of the correct reasons (unfamiliar water/depth, chance of injury).

- Similarly, as in the previous year, the majority of children knew about the risk of injury at home. They mentioned cutting with knives, touching the stove, being in the vicinity of appliances and wood stoves, moving through the kitchen or when food is cooking and jumping and running.

\section{Behaviour near train tracks}

- $1 \%$ of pupils did not know it was forbidden to play close to the tracks and $2 \%$ that it was forbidden to walk on the tracks. $7 \%$ did not know it was forbidden to cross anywhere other than at a crossing. Awareness-raising about the prohibition to play was evident in the question about dangerous places to hide, where children overwhelmingly list tracks, train stations and railways more often compared to the previous 
years. Awareness about the prohibition to play and walk was high from the beginning. There was a slight improvement in awareness regarding the prohibition to cross compared to last year.

\section{Partial summary of activities}

口 In the second project year, in a summarised perspective, the values across the project weeks were in the same range but slightly more favourable. The highest average proportion of correct answers was achieved in the 3rd and 6th project weeks about the topic "Principles when leaving a flat" and "Principles of good behaviour on the train and railway", where the median of the proportion of correct answers was above $90 \%$. On the contrary, the least favourable values for correct answers were found in the 7th project week "Getting lost in nature". However, as in the previous project year, question 3 remained the most problematic issue in the 6th project week. The only question with $100 \%$ correct answers is Question 5 in Project 8: "Select the correct uniform for firefighters to use in an emergency, which appeared in the tests for the first time. This time, the most balanced test results were achieved in the first project week.

\section{Results - Assessing Partial Research Question}

Research question no. 1: What is the initial level of competencies of pupils from socioeconomically disadvantaged backgrounds in the areas of safety and protection of health and life?

With regards to conducting the survey of the initial level of pupils in safety and protection of health and life, it is necessary to point out the existence of various threats, whether to health, life, property or the state. In each of the areas of the questionnaire research, there was a higher proportion of respondents whose answers stimulated discussion on awareness itself of risks and risky behaviour in their life and surroundings. The very fact that the term "emergency telephone numbers" was known to $60 \%$ of respondents highlights the necessity to address and deal with the issue of safety and protection. Alarming findings were in other critical topics of the initial level of pupils. $24 \%$ of pupils thought that a fire could not start from a small spark and $13 \%$ thought a match thrown into dry grass could not cause the same. In the area of protection of health, $30 \%$ of pupils would check themselves for ticks after a walk. $31 \%$ would wash their hands/body. The need for pedagogical help and support in these thematic areas is thus evident from the initial data. The basic presumption is that we avoid or are able to at least minimise such injuries, harm and losses and we could talk about/show what these risks/risky situations are and respond appropriately as part of practical lessons. It is thus to target the form of prevention through activities that lead to the preparation of children and pupils in an emergency. In the evaluation process, it was shown that testing the knowledge of pupils through this method is possible. However, it requires very precise preparation of the questions asked and consideration of the actual abilities of the children at different ages. The use of various questions and schematics where pupils may easily grasp the given situation and respond to the question with comprehension.

Research question no. 2: How were civic competencies of the target group of pupils from socioeconomically backgrounds perfected by the implementation of the project weeks?

In comparison to the results from the project weeks from both project years, the differences across the project weeks are evident at first glance. Meanwhile, perfection of the knowledge of students occurred in certain modules. Other modules kept presenting problems to pupils.

The most recognisable improvement occurred in the tests at the end of the second project week regarding the topic "When, where and how to correctly report an emergency". In the relevant test there was an improvement in results by even more than $20 \%$ compared to the previous year. In contrast to this in the seventh project week, "Getting lost in nature" and in the eighth project week "First responders and uniforms" and ninth project week "Fire, how to prevent it, its causes and consequences I", there was a slight worsening of results, though only in single digits of a percent.

Research question no. 3: How can the motivation of pupils be supported in the classroom to actively involve them in educational processes?

Given the tested activities that were connected to the implementing the project weeks it is evident that the education must be active for pupils and may actively involve them. Although the research was done within the after school programme, the recommendations below can be applied in the classroom. They are: employ non-traditional forms and methods of teaching; support the pupil communicating his/her practical experience about a given issue, especially the essence of communicating already obtained information; support awareness of the atmosphere in society - not only in the classroom but also in the environment where the pupil lives or is active; search for information together from a given area that can be worked with in a variety of ways, and create a situation and 
opportunity so that a pupil may verify his/her reactions, observations and thoughts. An integral task of teaching staff is the correct organisation of lessons and the use of community life around the school - communication with the local fire department, emergency rescue service...

\section{Conclusion, Discussion and Recommendation for Practice}

The primary practical recommendation is the constant need of specialist support for teaching staff, to improve accessibility of topic materials and support the importance of a topic through its appeal, which is what happened in implementing the project when there were visits by fire departments or excursions to integrated emergency response departments...

A further resulting recommendation is an awareness-raising activity or prevention that should cover not only an educational institution but also extracurricular activities that will prepare the pupil's knowledge about emergencies and support their protection. It may be a matter of activities (games, competitions, excursions...) that are held in the after school programme or as a part of children's leisure activities when they visit different activity groups.

The current system only shows the possibilities and what path is selected and whether attention will be paid to a topic in a given faith so that is would be attractive to the pupils depends on the teachers themselves. Therefore, the question remains whether the teaching materials for the teaching staff should be unified. Despite the wide spectrum of tests and aids, certain areas are prepared differently and do not always suit the given time and reflect the social events that may cause a threat. Therefore, unifying and updating materials would reinforces the topic and support the lesson. Multimedia and interactive textbooks can be used to make topics appealing.

The research done shows that it is suitable to inform and guide pupils in the first grade in the area of protect and safety in the form of games and exercises before memorising theoretical material itself. It is evident from this that we would target deepening theoretical knowledge with practical exercises in first aid during second grade. The basics of first aid and calling aid should be integrated into the whole cross-curricular education of protection of the citizenry. Further topics are obviously also necessary.

Another, no less important, topic is material safety, which is essential for obtaining such important practical knowledge for pupils, for example, using CPR manikins or simulators and first aid trainers. Financial support for educational materials and activities of individual interested subjects can be drawn from multiple sources - state, European and sponsors.

The role of the teacher is among the categories of factors that may influence not only the quality of information transmission but also the very motivation of the pupils. Society places various demands on teachers, and there is an expectation that these demands will be met. However, expectations differ, for example, from the school principal, school bodies, parents, pupils or school friends. Here it is evident that teaching staff will be better able to manage emergencies that occur and succeed in situations threatening their own health and life and those close and those entrusted to them, providing he/she is led to it personally and has the option to educate and develop themselves in this area. In the interest of leading school and staff, as well as principals, it is necessary to know that a team is created by employees who are prepared and are personally responsible not only for themselves but also their entrusted pupils and colleagues.

The involvement of parents into extracurricular activities is also a fact that may help along the topic being addressed. No less important is if one of the parents is in a profession connected to emergency response services. However, a parent is not always involved, and he/she is only a passive actor with regards to their child attending school. However, it concerns a child who is close to them and also from whom they hear what happened at school and what activities were done at school. Therefore, a parent may passively accept information from a given topic for a child.

The use of accessibility and coordination with the integrated emergency response system will no longer be referred to, if the idea that it is very effective for pupils is evident. However, the support of the profession that helps in an emergency - whether it is the fire brigade, police or physicians - becomes the stimulus... when a child may obtain his/her own professional role model, and a teacher may become a tool that helps make a child's wish a reality.

\section{Books}

Amaso, M. C. (2013). 100 Tips for a School Child's Daily Safety Guide. Xlibris Corporation.

Balabán, M., \& Pernica, B. et al. (2015). Bezpečnostní systém ČR: problémy a výzvy. Praha: Univerzita Karlova v Praze - Nakladatelství Karolinum. 
Čechová, B. et al. (2006). Nápadník pro rozvoj klíčových kompetencí ve výuce. Praha: Scio, s. 12.

Devine, J., \& Cohen, J. (2007). Making your school safe: Strategies to protect children and romote learning. New York: Teachers College Press.

Dnielsbacka, M. et al. (2017). Educational Test Scores among Adolescents in Three-Generational Households in 20 countries. Finnish Yearbook of Population Research 51.

Fiala, M., \& Vilášek, J. (2010). Vybrané kapitoly z ochrany obyvatelstva. Praha: Univerzita Karlova v Praze Nakladatelství Karolinum, s. 65.

Havlík, R., \& Kot’a, J. (2011). Sociologie výchovy a školy. Praha: Portál, s.r.o., s. 81.

Horská, V. (2002). Ochrana člověka za mimořádných událostí: text pro občanskou a rodinnou výchovu. Praha: Fortuna.

Chromíková, D. et al. (2008). Ochrana člověka za mimořádných událostí na 2. stupni ZŠ podle projektu NAPLNO. Pardubice: Občanské sdružení JAK?

Klinger, A., \& Klinger, A. (2018). Keeping Students Safe Every Day: How to Prepare for and Respond to School Violence, Natural Disasters, and Other Hazards. Virginia: Alexandria.

Kolektiv autorů. (2003). Ochrana člověka za mimořádných událostí Př́ručka pro učitele základních a středních škol. Praha: Ministerstvo vnitra - generální ředitelství Hasičského záchranného sboru ČR.

Kolektiv autorů. (2017). Rámcově vzdělávací program pro základní vzdělávání. Praha: Ministerstvo školství, mládeže a tělovýchovy ČR, s. 10, 125.

Kolkowicz, R. et al. (2019). Arms Control And International Security. New York: Routledge Taylor \& Francis Group.

Martínek, B. (2009). Ochrana obyvatelstva I.: skripta. Praha: Policejní akademie České republiky v Praze.

Martínek, B. (2014). Metodický manuál pro přípravu preventistů ochrany obyvatelstva. Sdružení hasičů Čech, Moravy a Slezska: Ústřední hasičská škola Jánské Koupele.

Matějů, P., \& Večerník, J. (1998). Zpráva o vývoji české společnosti 1989- 1998. Praha: Academia, s. 59.

Pinquart, M., \& Sörensen, S. (2000). Influences of socioeconomic status, social network, and competence on subjective well-being in later life: a meta-analysis. Psychology and aging, 15(2).

Rabušicová, M., \& Pol, M. (1996). Vztahy školy a rodiny dnes: hledání cest k partnerství. Praha: Pedagogická fakulta Univerzita Karlova, Pedagogika 46.

Reeves M. A., \& Kanan L. M. (2010). Comprehensive Planning for Safe Learning Environments. New York: Routledge Taylor \& Francis Group.

Sak, P. (2018). Úvod do teorie bezpečnosti Nekonvenční pohledy na minulost, prítomnost a budoucnost lidstva. Havlíčkův Brod: Petrklíč.

Stárek, L., \& Klugerová, J. Chování. (2018). Žáka v mimořádných situacích jako možnost inkluzivního př́stupu (The behavior of student in emergency situation as a way to inclusion approach). In Inkluzivne pristupy v edukácii detí a žiakov. Slovensko: VERBUM - vydavatel'stvo Katolíckej univerzity v Ružomberku.

Stárek, L., \& Klugerová, J. (2018). Občanské a sociálni kompetence u žákủ základních škol v kontextu socioekonomicky znevýhodněného prostředí. s. 16-19. Forum sociální politiky: odborný recenzovaný časopis. Praha: Výzkumný ústav práce a sociálních věcí, 12(6).

Sulkowski M. L., \& Lazarus P. H. (2017). Creating Safe and Supportive Schools and Fostering Students' Mental Health. New York: Routledge.

Šotkovský, I. (2012). Socioekonomická geografie - prostředi lidské činnosti. Ostrava: Vysoká škola báňská Technická univerzita Ostrava.

Veteška, J. et al. (2011). Teorie a praxe kompetenčního př́stupu ve vzdělávání. Praha: EDUCA Service, s. 83.

Zpěvák, A. et al. (2014). Ochrana obyvatelstva v republikovém měřitku. Praha: Univerzita Jana Amose Komenského Praha. 


\section{Web Pages}

EUROPEAN COMMISSION. Education and Training - Monitor 2019, Country analysis. [online].. Dostupné z: Retrieved from https://ec.europa.eu/education/sites/education/files/document-library-docs/volume-2-2019-education-and-trainin g-monitor-country-analysis.pdf

MINISTERSTVO VNITRA - GENERÁLNÍ ŘEDITELSTVÍ, HASIČSKÉHO ZÁCHRANNÉHO SBORU ČESKÉ REPUBLIKY. Podpora vzděláváni na pedagogických fakultách. [online]. [cit. 2019-12-06]. Dostupné z: Retrieved from https://www.hzscr.cz/clanek/podpora-vzdelavani-na-pedagogickych-fakultach.aspx

\section{Legal Source}

Act no. 239/2000 Sb., On the Integrated Protective System and Amendments to Some Laws, as amended. In: Collection of laws of the Czech Republic.

Act No. 240/2000 Coll., On crisis management and amending certain acts (the Crisis Act). In: Collection of laws of the Czech Republic.

Act No. 320/2015 Coll., On the Fire Rescue Service. In: Collection of laws of the Czech Republic.

Act No. 561/2004 Coll., On pre-school, primary, secondary, tertiary professional and other education (Education Act). In: Collection of laws of the Czech Republic. 